speaks to such problems in the field of archaeology: "Presumably archeologists feel their subjects are dead and buried... and that they are not implicated in the representation and struggles of living peoples."35 Such assumptions, Meskell illustrates, are false; examples abound of communities in the present struggling for "rights" to the past, as in the case of "Augustine the Algerian." In light of postcolonial identity politics, can one speak of "Tertullian the Tunisian?"36

If Patristic scholarship is going to engage in Postcolonial re-readings of the early Church documents, there are some immediate objections that should be answered. Many classics departments are still realing from debates over Black Athena. Should Patristic scholars trade a Euro-centric reading for an Afro-centric one? While one could argue for the validity of such an approach, the present study will turn to another discipline for methodology.

In order to address the postcolonial history of Tertullian, an "African theologian," this present work will turn to the discipline of Social Anthropology. 37

\title{
1.2 An Anthropological "Writing" of Tertullian
}

In order to succinctly survey the socio-political context of Tertullian and then in turn to allow the findings of said survey to provide a paradigm for interpreting the African theologian, the following chapters will embark on a Postcolonial reading of the sources using theories and methods from the field of Social Anthropology. It is suggested here that Social Anthropology provides theories that can aid the work of historical theologians in "rereading" a postcolonial setting. Although the assimilation of Postcolonial discourse into the discipline of Social Anthropology needs no defense in light of the amount of works produced in this genre by anthropologists, a few words explaining the correlation of the two fields will prove helpful. After doing so, some general comments will be made about Social Anthropology, especially in relation to historical studies.

Decentering Biblical Scholarship," $J B L 107$ (1988): 3-17. For further discussion on postcolonial, feminist, and other "cultural" theories' impact on patristic scholarship, see essays in Dale B. Martin and Patricia Cox Miller, ed., The Cultural Turn in Late Ancient Studies: Gender, Asceticism and Historiography, (Durham: Duke University Press, 2005).

35 "The Intersection of Identity and Politics in Archaeology," ARA 31 (2002), 280.

36 For a review and discussion of "identity" in terms of "identity politics," see Kevin Hetherington, Expression of Identity: Space, Performance, Politics, (London: SAGE, 1998).

37 The distinction between Social Anthropology (British), and Cultural Anthropology (American), is often transcended in actual practice by anthropologists who read and cite scholars from both sides of the Atlantic, as is done in what follows. 


\subsubsection{Postcolonial Anthropology}

Since anthropologists often carry out their fieldwork in Postcolonial contexts, some scholars have applied various understandings of such encounters. Olivia Harris outlines six "models" found, either explicitly or implicitly, in anthropological studies:

(1) Mixing or creolization - presupposes fixed points of origin for each "culture"

(2) Colonisation - assumes the superiority of colonizer over colonized

(3) Borrowing - allows more agency to the colonized

(4) Juxtaposition or alternation - permits individuals to inhabit contradictory or irreconcilable "knowledge systems" simultaneously

(5) Imitation or direct identification - requires rejection of past "knowledge or cultural form" in order to acquire a new "identity"

(6) Innovation and creativity - attributes priority to "autonomy and independent agency" over contrasting groups or "knowledge systems."

In this present work, the understanding of encounter will draw more from specific theories within the field of anthropology, all of which have responded and adapted in their application to postcolonial contexts. Before turning to those theories, however, a brief analysis of how the Postcolonial perspective has been incorporated into Social Anthropology is needed.

Social Anthropology as a discipline aligns neatly with a Postcolonial reading of history in two ways: (1) because anthropology has, in recent decades, been eagerly introspective, a large consensus of anthropologists has regarded Postcolonial criticism; and (2) many anthropological theorists readily assimilate, and sometimes even promote, postcolonial perspectives.

Although Postcolonial critics have in the past attacked Social Anthropology as an active enabler and participant of the colonial process - a fact rarely denied by anthropologists, many anthropologists have accepted the Postcolonial challenge and proactively amalgamated Postcolonial theory as a corrective into their own discipline to the point it could be considered mainstream. ${ }^{39}$ Social Anthropology has largely been a self-critical discipline, recognizing the need to analyze both the observed and the observer, a principle known as "reflexivity."40

38 "Knowing the Past: The Antinomies of Loss in Highland Bolivia," in Counterwork: Managing the Diversity of Knowledge, ed. Richard Fardon, (London: Routledge, 1995), 112-3.

39 T.H. Eriksen, Small Places, Large Issues: An Introduction to Social and Cultural Anthropology, 2nd ed., (London: Pluto Press, 2001), 15; cf. the earlier analysis of T. Asad, "Introduction," Anthropology and the Colonial Encounter, ed. T. Asad, (London: Ithaca, 1973), 9-19. For a dissenting voice, however, see Vassos Argyrou, Anthropology and the Will to Meaning: A Postcolonial Critique, (London: Pluto Press, 2002), who argues that even postcolonial anthropology has a self-centered humanistic agenda and the anthropological project is forever doomed to failure.

40 Alan Barnard, History and Theory in Anthropology, (CUP, 2000), 164. See Takeyuki Tsuda, "Ethnicity and the Anthropologist: Negotiating Identities in the Field," $A Q 71$ (3 1998): 107- 
Therefore, when critics as far back as Said began to criticize anthropologists, many scholars responded with an introspection that resulted in the conjoining of Postcolonial theory to their own work. ${ }^{41}$

Many anthropologists readily align themselves with the aims and principles of Postcolonial theory, finding a like-mindedness inherent between the two fields. The confrontation of the two disciplines was inevitable in that Postcolonialism arose as a critique of the West's portrayal of the "Other," a blow for Social Anthropology because "anthropology's historical concern has been largely with non-western peoples." Alan Barnard traces the conjoining between the two disciplines back to the influence of E.E. Evans-Pritchard and Clifford Geertz. ${ }^{43}$ The influence, as Barnard sees it, began with "Evans-Pritchard in his rejection of the idea of anthropology as a science, in favour of an interpretive approach which placed anthropology firmly within the humanities."44 Barnard also says EvansPritchard allowed for the historian's diachronic approach over the traditionally synchronic approach of anthropology. ${ }^{45}$ Geertz expounded on the understanding of anthropology as an interpretive endeavor shifting the methodology from a linguistic understanding of "translating" a "grammar" (i.e. a "culture"), to a more complex "writing" of a "thick description" of a society and its values and practices. ${ }^{46}$ Commenting on the reflexivity prompted by Postcolonial critiques, Geertz asks and answers,

What, after all, is one to make of savages? ...For the anthropologist, whose profession it is to study other cultures, the puzzle is always with him. His personal relationship to his object of study is, perhaps more than for any other scientist,

24 , for a discussion of how the ethnographer's ethnic identity impacts the interaction with informants, and for a good survey of reflexivity and the discussions of the anthropologist as objective observer of subjects versus an active subject in the ethnographic interaction. For a comparison with the "reflexive sociology" of Bourdieu, see Simon J. Charlesworth, $A$ Phenomenology of Working Class Experience, (CUP, 2000).

41 Barnard, History, 167, who also cites anthropologists, like Asad, who "anticipated" Said's critique.

42 Richard Fardon, "Introduction: Counterworks," in Conterworks: Managing the Diversity of Knowledge, ed. Fardon, (London: Routledge, 1995), 1. For a classic example, see A.R. Radcliffe-Brown, Structure and Function in Primitive Society, (New York: Free Press, 1952), 2-3, who defined anthropology as a "branch of sociology" which studies "primitive societies."

43 History, 158-164.

44 Ibid, 158; ref. E.E. Evans-Pritchard, Essays in Social Anthropology, (London: Faber \& Faber, 1962), 13-28, who contends for anthropology as part of the "humanities" instead of "science"; and Evans-Pritchard, The Position of Women in Primitive Societies and Other Essays in Social Anthropology, (London: Faber and Faber, 1965), esp. 33-5.

45 History and Theory, 162.

46 "Thick Description: Toward an Interpretive Theory of Culture," The Interpretation of Cultures: Selected Essays, (New York: Basic Books, 1973), 3-30. For a recent criticism of Geertz, see Adam Kuper, Culture: The Anthropologist's Account,(HUP, 1999). For a New Testament scholar's criticism of a "thick description" approach, see Justin J. Meggitt, Paul, Poverty and Survival, (Edinburgh: T\&T Clark, 1998), 39. 
inevitably problematic. Know what he thinks a savage is and you have the key to his work. You know what he thinks he himself is and, knowing what he thinks he himself is you know in general what sort of thing he is going to say about whatever tribe he happens to be studying. All ethnography is part philosophy, and a good deal of the rest is confession. ${ }^{47}$

Because of the ideas forwarded by these two anthropological theorists, Barnard says, "Interpretivism and postmodernism fit into anthropology in a very straightforward way...."48 In recent years, therefore, anthropologists align themselves squarely within the critical framework of a Postcolonial reading - or "writing" - of history. ${ }^{49}$

\subsubsection{Social Anthropology - Past, Purpose and Method}

Although some anthropologists trace their disciplinary descent back to Herodotus (c.484-c.431 BCE) as the founder of the discipline, Eriksen claims that Tertullian's fellow Tunisian, Ibn Khaldun (1332-1406 CE), the author of the Muqaddima ("Introduction to History"), is a more credible methodological progenitor because Khaldun introduced "theory" into the discipline of observation. ${ }^{50}$ Most genealogies of anthropology, however, begin with European colonial expansion and the resulting need for "the classification of the 'peoples' of the world, the attribution of specificity to bounded populations." entire history with all of the ranging debates need not - and could not - be recounted here, the following sections of this chapter will trace much of the disciplines past by reviewing the differing approaches to specific theories. One debate from early anthropological discourse that will prove to be a beneficial starting point is the relativist/universalist dispute first underscored by Franz Boas.

Boas understood much early fieldwork to be misguided in that it too often attempted to "fit" information into a universal theory of humanity, and so his emphasis on ethnography and data collection for its own sake became known as the particularist approach. ${ }^{52}$ Varying reactions arose after Boas including the

47 The Interpretation, 345-6. "Ethnography" is traditionally defined as the anthropologist's fieldwork, or the observing of "facts"; see, however, Geertz, "Thick Description," 6.

48 History, 175. For bibliography on the "invention of tradition," see Charles L. Briggs, "The Politics of Discursive Authority in Research on the "Invention of Tradition," CA 11 (4 1996): 435-69. For this debate in relation to identity, see the case studies in Jonathan Friedman, "The Past in the Future: History and the Politics of Identity," AA 94 (4 1992): 837-59.

49 i.e. Gcertz' "writing a thick description" of ethnographic interpretation; see more on Geertz below in section 6.1 on religion.

50 Small Places, 10; cf. Ibn Khaldûn,The Muqaddimah: An Introduction to History, 3 vols., trans. Franz Rosenthal; ed. N.J. Dawood, (London : Routledge, 1978).

51 Friedman, "The Past," 846.

52 Fiona Bowie, The Anthropology of Religion: An Introduction, (Oxford: Blackwell, 2000), 178. 
approach known as "structuralism" - the school of thought that replaced functionalism in anthropology - championed by Claude Levi-Strauss, which sought to form a universal theory of the human mind that under-girded the structures of all societies. ${ }^{53}$ Later, Edmund Leach claimed that a strict Boasian approach without the counterbalance of a "generalization" amounted to little more than anthropological "butterfly collecting.,"

In current debates universalists and particularists remain at odds in their respective hope or skepticism regarding a meta-theory that can incorporate all variations in specific contexts and societies. Eriksen summarizes,

To what extent do all humans, cultures or societies have something in common, and to what extent is each of them unique? Since we employ comparative concepts - that is supposedly culturally neutral terms like kinship system, gender role, system of inheritance, etc. - it is implicitly acknowledged that all or nearly all societies have several features in common. However, many anthropologists challenge this view and claim the uniqueness of each culture or society. ${ }^{55}$

While some of the "many" challenges will be discussed further below, it should be noted how problematized any universalist stance - often characterized as "the phenomenological approach" - has become. F.C. Wallace eloquently lamented such a problematic: "It is always hazardous to set forth in search of the headwaters of human institutions. The unwary scholar is all too apt to find himself soon mired in a noisome bog of speculations, unable to extricate himself with dignity and subject to stoning by his more prudent colleagues on the bank." Although any universalist stance is argued by particularists to be unacceptable, many anthropologists argue that a phenomenological approach should nevertheless serve as a methodological ideal.

For present purposes, the method of balancing fieldwork with theory provides the primary benefit in understanding and accommodating Social Anthropology. As Ioan M. Lewis insists, "I maintain that a continuous dialogue between theory and empirically observed data is the essential basis of a vigorous, substantive social anthropology." $" 57$ Ethnography - "empirically observ[ing] data" - allows any forwarded theory to be tested by other anthropologists. Even an interpretivist like Geertz notes the necessary evil of debated theory: "Anthropology... is a science whose progress is marked less by a perfection of consensus than by a refinement of debate. What gets better is the precision with which we vex each

53 Ibid, 19.

54 Rethinking Anthropology, rev. ed., (London: Athlone Press, [1961]1997), 2.

55 Small Places, 5-6.

56 Cited in Morton Klass, Ordered Universes: Approaches to the Anthropology of Religion, (Boulder, CO: Oxford: Westview Press, 1995), 8.

57 Arguments with Ethnography: Comparative Approaches to History, Politics and Religion, (London: The Athlone Press, 1999), xii. 
other." 58 Likewise, David Schneider, the self-lauded "culturalist," speaks of the centrality of debate between theory and fieldwork when he observes, "The aims and methods of anthropology have always been and are always being sharply criticized and generally overhauled." $"$ Whenever scholars forward theories in anthropology, they expect criticism from their peers; many theories can be reformulated and adapted; many are discarded. The cardinal sin, however, for an anthropologist is ethnocentrism.

Any theory claimed to apply "universally" must meet the challenge of scholars who would scrutinize it seeking an indication of ethnocentricism. David Hicks comments, "...the sharp distinction scholars once made between 'us' and 'them' is no longer part of mainstream thinking, and the use of such terms as primitive or savage to describe the customs of other people are outdated modes of reference that may give us more insight into the ideological assumptions of our own not-too-distant scholarly ancestors than into the thinking of members of other cultures." and correlate to - if not condition, or even cause - the Postmodern critique of essentialism. $^{61}$ Such critiques, it is argued here, align positively with historical methods, which strive to overcome anachronism. ${ }^{62}$

\subsubsection{Anthropology and History}

Anthropology and history as academic fields have enjoyed a long and fruitful interdisciplinary relationship. Although many early studies within anthropology inappropriately sought to find the "origins" of humankind by studying the remnant of "primitive" peoples - some of which will be surveyed below, anthropology as a general discipline corrected this appropriating of the past and has now come full circle in that many anthropologists are critiquing the historiography of others. Kevin Yelvington, commenting on the "plethora" of anthropological studies of history, provides a helpful analysis of how anthropologists "construct relevant typologies" for the past. ${ }^{63}$ Yelvington argues that academic departments of history currently face a "crisis of epistemology" which can only be overcome through the supplementation of an anthropological understanding of history. ${ }^{64}$ Anthropologists, Yelvington suggests, are especially

58 “Thick Description," 29.

59 A Critique of the Study of Kinship, (UMP, 1984), 201.

60 "Introduction," in Ritual and Belief: Readings in the Anthropology of Religion, ed. Hicks, (Boston: McGraw-Hill College, 1999), viii.

61 Several discussions of anti-essentialism will be outlined below in relation to specific theories.

62 For similar argument, cf. MacDonald, Early Christian Women, 14-5, where anthropology provides biblical scholars with a "sensitivity" to ethnocentrism as well as anachronism.

63 Kevin A. Yelvington, "History, Memory and Identity: A Programmatic Prolegomenon," $\mathrm{Cr} A$ 22 (3 2002), 3.

64 Ibid, n.5. 
trained to examine "history as representation," because so many representations of the past involve "political" and "ideological" elements. ${ }^{65}$

Yelvington cites and reiterates the arguments of J. Friedman, who insists that history always involves a "construction" of the past. ${ }^{66}$ "'Objective' history," Friedman declares, "...is just as much a social construct as any other history, and it cannot be simply accepted at face value." problematizes any "objective" claims in historiography is that "history is the discourse of identity" - as seen in the example of Augustine above. ${ }^{68}$ The importance of "identity" for any historical study, and in this case for Tertullian, once again highlights why anthropological theories provide the historian with an approach that assists in the safeguarding against anachronism - the historians' unpardonable sin - and against ethnocentrism - that which must be avoided at all costs by anthropologists. Whether or not Social Anthropology provides the only means of overcoming any "epistemological crisis" for historians, a number of researchers who have amalgamated the fields of History and Social Anthropology benefit from anthropological theory applied to history, especially the history of Postcolonial contexts.

Because often in Postcolonial contexts "the past is frozen as an eternal validation of the present," Ian Fowler and David Zeitlyn address the need for focusing on identities in an anthropological history. ${ }^{69}$ Their argument claims to be especially apt for African examples: "Ethnography and history are nowhere more tightly bound up with identity and ethnicity than in the broad field of colonial and post-colonial African studies." ${ }^{70}$ While these authors speak especially in terms of the events of the last century, in light of the application of Postcolonial theory to Roman imperialism and in light of the identity politics that accompany studies of ancient individuals such as Augustine, their insights adequately depict the issues accompanying a Postcolonial re-reading of Tertullian which will rely on anthropological theories of identity. The present discussion, therefore, can now turn to these specific theories to understand how anthropologists have formulated anti-ethnocentric, anti-essentialist and antianachronistic ideas about social identity, kinship, class, ethnicity and religion.

Theories from Social Anthropology have enjoyed a renewed usage among archaeologists and ancient historians. ${ }^{71}$ It is true that a few scholars, such as K.J. Matthews, reject any "borrowing" of theory and prefer to claim their "roots are in the dirt of the archaeological site, the best foundation for a truly archaeological

65 Ibid, 5-6.

66 Friedman, "The Past."

67 Ibid, 854.

68 Ibid.

69 "Preface," in African Crossroads: Intersections between History and Anthropology in Cameroon, ed. Fowler and Zeitlyn (Oxford: Berghahn Books, 1996), xix. Similarly, Bediako, Theology, 426-7, suggests that "the question of identity constitutes a "hermeneutical key.""

70 Fowler and Zeitlyn, "Preface," xviii.

71 For discussion, see Laurence, "Introduction," 1-9. 
theory."72 However, despite the insistence of some to keep their methodological head in the sand, many archaeologists have turned to anthropological theory to assist in the interpretation of their findings. ${ }^{73}$

A strong proponent of anthropological theory among Classicists is S.C. Humphreys, who criticizes historians' presumptions about objectivity: "Historians and philologists share a bit of leaving their assumptions about psychology, culture and social relationships unstated - and even, for the most part, consider this a positive virtue."74 Explaining the usefulness of social theory, Humphreys explains, "Anthropologists are not likely to offer us help with filling in the blanks in our knowledge of Bronze Age kinship or religion. But they can offer a framework within which we can try to put together fragments of Greek culture and society studied in isolation, into a coherent whole. And this does seem to be a crucial need at present for Classical Studies generally.,"75 More recently, John Scheid promotes Anthropology for similar reasons in that it "offers an excellent school of thought and a methodology that will help to distance us from our ethnocentrism and to "decolonise" Roman studies. ${ }^{76}$ This decolonizing refers especially to the "Other" of ancient history, as is discussed by Simon Goldhill, the editor of a work similarly interested in identity in the Roman world, who bemoans the problem: "[Anthropology's] direct effect on classics has been small, in part because the opportunities of studying 'working class' (slave, helot, latifundia, poor man, even female) culture are severely handicapped by the largely elite evidence which survives."77 Similarly, Huskinson insists that historians should concern themselves as much with ethnocentrism as with anachronism in order "to hear the hitherto 'silent voices' in Roman society."

Analogously, the field of early Christian studies has started to integrate social theory into its re-presentations of the past. In what has become known as socialscientific criticism, biblical scholars in recent decades have begun to implement models and theories from Social Anthropology to the ancient near east in order to answer similar questions. ${ }^{79}$ A similar approach could add further insight into the

72 “Archaeological Data, Subculture and Social Dynamics," Antiquity 69 (1995), 592.

73 P.S. Wells, "Identity and Material Culture in the Later Prehistory of Central Europe," JArR 6 (1998): 239-298. For the current state of the relationship (or lack thereof) between the disciplines of Archaeology and History in general, see Laurence, "Introduction."

74

75

Huskinson, "Introduction," 1

79 For a review, see D.G. Horrell (ed.), Social-Scientific Approaches to New Testament Interpretation, (Edinburgh: T \& T Clark, 1999). For anthropology in particular, see Lawrence and Aguilar (eds.), Anthropology and Biblical Studies. For an alternate critique of Christian origins scholars' claim to "an objectivist reconstruction of early Christian history" as "a 
scholarly interpretation of Tertullian's writings. ${ }^{80}$ While this project primarily concerns itself with Tertullian's African identity, in one sense Tertullian is a case study for the usefulness of identity theory in Historical Theology.

\subsection{Patristic Readings of Tertullian}

In order to review the scholarly assertions on Tertullian's biographical information, it will prove helpful to return to Bardenhewer's summary - cited in full in this introduction. His synopsis will provide the outline for a discussion of the research into Tertullian's life: his name, his birth, his father, his education, his occupation (a jurist, which will call into question his relationship to sophistry and philosophy), his conversion, his ordination, and his schism. Since most scholars now agree with Bray's conclusion that "we know virtually nothing about Tertullian's life," the evolution from the general consensus of scholars in Bardenhewer's time to the accepted axiom of Bray will be presented here, not in a purely chronological form, but thematically. ${ }^{81}$ The scholar who most persuasively contested the life of Tertullian as outlined above, Timothy David Barnes, will be followed closely in the following paragraphs. ${ }^{82}$ The following section will outline and illustrate the debate over Tertullian's life, showing the issues affecting the deconstruction of Tertullian's biography by recent scholars.

scholarly fiction," see Fiorenza, "'You are not to be Called Father': Early Christian History in a Feminist Perspective," Cross Currents 29 (3 1979): $301-23$.

80 Judith M. Lieu, Christian Identity in the Jewish and Graeco-Roman World, (OUP: 2004), 15-7, argues for this move specifically for theories of identity in first and second century Christianity. Similarly, J. Patout Burns, Jr., Cyprian the Bishop, (London: Routledge, 2002), applies Mary Douglas' approach to group identity and boundaries. Also, Maureen A. Tilley, The Bible, 6, has suggested the use of sociology of religion in studying the Donatist controversy. For a sociological reading of early Christian history in general, see Rodney Stark, The Rise of Christianity: A Sociologist Reconsiders History, (Princeton: Princeton University Press, 1996). For an attempt to set theology and anthropology in dialogue more generally, see Douglas $\mathbf{J}$. Davies, Anthropology and Theology, (Oxford: Berg, 2002).

81 Bray, Holiness, 8-9.

82 T.D. Barnes, Tertullian: An Historical and Literary Study, (Oxford: Clarendon Press, 1971). For pre-Barnesian bibliography of Tertullian studies up to 1954 , see CCSL I, xii-xiv; and the website by Roger Pearse, http://www.tertullian.org; although it is sometimes tenuous to cite webpages in scholarly works, a number of recent scholarly reviews have brought Pearse's work into the mainstream of Tertullian scholarship: Revue d'Études Augustiniennes 44 (1998): 339; Ian L.S. Balfour, "Tertullian on and off the Internet," JECS 8 (4 2000), 581; Dunn, Tertullian, 1; Pierre Petitmengin, Revue d'Études Augustiniennes 50 (2004): 393; and Vincent Hunink, Tertullian: De Pallio, (Amsterdam: J.C. Gieben, 2005), 12. 